\title{
Okul Öncesi Eğitime Başlangıçta Yaşanılan Uyum Sürecine İlişkin Ebeveynlerin Görüşleri
}

DOI: $10.26466 /$ opus.571801

\author{
* \\ Ayhan Bulut* \\ ${ }^{*}$ Dr. Öğr. Üyesi, Bayburt Üniversitesi, Eğitim Fakültesi, Bayburt / Türkiye \\ E-Posta: ayhanbulut@bayburt.edu.tr \\ ORCID: 0000-0001-6482-8032
}

\section{Öz}

Bu araştırmanın amacı, okul öncesi eğitime başlangıçta yaşanılan uyum sürecine ilişkin ebeveynlerin görüşlerini belirlemektir. Bu araştırmada nitel araştırma desenlerinden durum çalışması yöntemi kullanılmıştır. Araştırmanın çalışma grubunu 2018/2019 eğitim öğretim yılında Erzurum iline bağhl üç merkez ilçede, çocukları okul öncesi eğitim kurumlarına ilk defa başlayan ve devam eden 36-48 aylık yaş aralı̆̆ına sahip çocuklarm ebeveynleri arasından gönüllü olarak çalışmaya destek vermek isteyenlerden oluşturulmuştur. Bu araştırma örnekleminin otuz üçünü bayan ve yedisini erkek olmak üzere toplam kırk ebeveyn oluşturmaktadır. Araştırmanın veri toplama sürecinde araştırmacı tarafindan geliştirilen yarı yapılandırılmış görüşme formu kullanılmıştır. Araştırma sonuçlarına göre, ebeveynlerin okula uyum sürecinde yaşadıklarına ilişkin olarak en çok çocuklarının ayrılık kaygııı içerisinde olduklarını ve okula gitmek istemediklerini belirtmişlerdir. Aynı süreçte çocuklarının öğretmeniyle yakın iletişim içerisinde olduklarını, çocuklarının okula alışıncaya kadar okulda onunla birlikte kaldıklarını ifade etmişlerdir. Bununla birlikte çocuklarını bu dönemde sık sık ziyaret ettiklerini, kendilerini sorguladıkların ve süreç boyunca gergin oldukların belirtmişlerdir. Ebeveynler aynı süreçle ilgili olarak çocuklarının öğretmeniyle ve okul yönetimleriyle iletişimlerini olumlu cümlelerle ifade ederken okul rehberlik servislerinden konuyla ilgili daha fazla destek beklediklerini ifade etmişlerdir. Ayrica ebeveynler bu süreci yaşayacak olan diğer ailelere süreç boyunca sabırlı ve kararlı olmalarmı, ailenin bütün üyelerinin bu süreçte birlikte hareket etmesinin gerekliliğini vurgulamışlardır. Bununla birlikte çalışmaya katılan ebeveynlerin okul öncesi eğitimin zorunlu olması yönünde görüş bildirdikleri tespit edilmiştir. Araştırma bulguları literatüre dayandırılarak tartışılmış ve açıklanmaya çalışılmıştır.

Anahtar Kelimeler: Ebeveyn, okula uyum, okul öncesi 


\title{
Parents' Opinions on the Adaptation Process at the Beginning of Preschool Education
}

\begin{abstract}
The aim of this study is to determine the views of parents about the adaptation process that was initially experienced in pre-school education. In this study, the case study method was used from qualitative research designs. The study group of the study consisted of volunteers who want to support the study voluntarily among the parents of children between the ages of 36-48 months who started their preschool education institutions for the first time in three central districts of Erzurum province in 2018/2019 academic year. The sample of the study consisted of thirty-three women and seven men. The semi-structured interview form developed by the researcher was used in the data collection process. According to the results of the study, they stated that their children are in a concern of separation and do not want to go to school. During the same period, they stated that their children were in close contact with their teacher, that the children were staying with him at school until they were used to school, and that they frequently visited their children during this period, and that they were questioning themselves during the process and that they were nervous throughout the process. Parents expressed their children's communication with their teachers and school administrations positively in relation to the same process and expressed that they expected more support from the school guidance services. In addition, parents emphasized the need to be patient and determined throughout the process, and that all members of the family should act together in this process. However, the parents who participated in the study stated that preschool education should be compulsory. The research findings were discussed and explained based on the literature.
\end{abstract}

Keywords: Parent, school adaptation, preschool. 


\section{Giriş}

Okul öncesi eğitim; çocuğun doğumundan itibaren başlayarak temel eğitime başlayacağı geçen güne kadar devlet veya özel kurumlarca verilen, çocukları nitelikli ve planlı şekilde temel eğitime hazırlayan eğitim kurumlarına verilen isimdir (Şepitçi, 2018). Başka bir ifadeyle çocukların sağlıklı bir biçimde sosyal, dilsel, bilişsel, duygusal ve psikomotor açıdan tüm gelişim evrelerini destekleyerek, çocuğun içinde büyüdüğü toplumun kültürel değerlerini kendi gelişimlerine uygun olacak şekilde öğretmeye çalışan ve onların kişilik ve yapısının şekillenmesinde çok önemli bir yere sahip olan örgün eğitimin ilk sürecidir (Aslanargun ve Tapan, 2012; Balaban, 2017). Okul öncesi eğitim süreci çocuğun gelişim ve değişim sürecinin en hızlı yaşandığı dönemdir. Bu dönemde çocuk kendisine verilen eğitimin niteliğine göre yaşantısında kalıcı izli davranış değişiklikleri oluşturmaya başlar (Şahin, 2000).

Okul öncesi eğitim kurumları çocuğun örgün eğitime başladığı ve onun bundan sonraki yaşantısına şekil verecek çok önemli bir yerdir. Çocuk için okul öncesi eğitim kurumları bu anlamıyla da aileden ayrıldığı, kendi ayaklarının üzerinde durmaya başladığı, kendi sorumluluklarını yavaş yavaş almaya başladığı ve sosyalleşmesinin kapısını araladığı bir çevrenin varlığını yansıtır. Okula uyum sürecinin niteliğini çocuğun okula hazır bulunuşluk seviyesine, sosyo ekonomik durumuna, ailenin eğitim durumu ve çocuğun yaşadığ çevrenin demografik özellikleri gibi birçok etkene bağlıdır (Reynolds and Bezruczko, 1993).

Bununla birlikte çocuk için okula başlama birçok yönüyle yeni ve zorlu bir süreci içerir. Çünkü okula başlama onlar için o ana kadarki yaşamlarında karşılaştıkları en köklü ortam değişikliğidir. Çocuk için bu dönemde yaşadıkları sosyal ve davranışsal problemler onların bundan sonraki okul yaşantılarını da olumlu veya olumsuz olarak etkileme potansiyeline sahiptir (Ladd, Price, 1987). Çocuk okula başladığı ilk günden itibaren öğretmen ve arkadaşlarıyla uyumlu davranışlar sergileyebilir veya bu yeni duruma hiçbir tepkide vermeyebilir. Bu süreçte çocuğun ağlaması, anneye veya babaya karşı bağımlı davranışlar göstermesi veya çevresine karşı agresif davranışlar geliştirmesi bu sürecin iyi gözlenmesini ve önlem alınmasını gerektirebilir. Bunun yanı sıra çocuklar gecikmiş tepkilerde ve- 
rebilir. İçine kapanık olarak verilen bu tepkiler, çeşitli davranış problemleriyle bu dönemde karıştırılabileceği için göz ardı edilebilir. Tüm bu nedenlerden dolayı ebeveynlerin ve öğretmenlerin bu dönemde çocuklar üzerinde oldukça dikkatli bir şekilde gözlemler yapması gerekir (Deretarla G,E. 2019).

Uyum kavramsal olarak bireyin sahip olduğu özelliklerden yola çkarak, içinde yaşadığ 1 çevreyle dengeli bir ilişki ve iletişim kurarak bu süreci yaşamı boyunca sürdürebilmesidir (Yeşilyaprak, 1989). Okula uyum ise kavramsal olarak çocukların yeni ve farklı bir eğitim iklimine geçiş ve bu geçişte istenilen amaca ulaşması olarak tanımlanabilir (MEB, 2015).

Okula uyum kavramı, çocuğun sosyal çevreden gelen dış uyarıcılara karşı gösterdiği davranışsal ve akademik tepkilerin tümünü ifade eder. Bu süreçte yaşanılan sıkıntıların varlığı ve içeriği onların okula uyum sürecini olumsuz yönde etkileyebilir (Gresham ve Elliott, 1987; Seven, 2011). Okul öncesi eğitime başladığı dönemde çocuk; ebeveynlerine yoğun şekilde bağlllık duyduğundan kendini güvende hissettiği aile ortamından ayrılarak; yeni bir ortama girdikleri için çeşitli problemlerle karşı karşıya kalabilirler. Çocuğun yeni sürece en hızlı ve güzel şekilde alışarak bu uyum sürecine aşması oldukça önemlidir (Kaya ve Akgün, 2016).

Aydoğmuş (2001) göre okula başlangıçta, okula gitmek istemeyebilir, bu dönemde okul korkusu ve kaygısı da geliştirebilir. Bunun temel sebebi anneden ayrı kalacağı düşüncesi ve korkusudur. Durak'a (2011) göre çocukların büyük bir bölümünde okula başladıkları ilk zamanlarda çeşitli şekillerde kendini gösteren uyum sıkıntıları olabileceğini ifade etmiştir. Bu problemlerin önemli bir bölümü okulun açıldığı ilk haftalarda çözülür. Ancak öğrencilerin bireysel farklılıkları, ailenin konuyla ilgili yaklaşımları ve tutumları bu sürecin uzamasına neden olabilir. Çocuklar, ebeveynlerinin ve öğretmenlerinin bu süreçte birbirleriyle yakın iletişim halinde olduklarını gördüklerinde kendilerini daha güvende hissederler (Carlisle. E., Stanley, L. and Kemple K.M 2005).

Ebeveynlerin bu dönemde okulla ve çocuğunun öğretmeniyle kuracakları ilişkinin niteliği ve sıklığı çocukta okul korkusunun oluşmasını engelleyecektir (Kıldan, 2012). Okul korkusunu yenmek için aileler okula başlangıç sürecinde çocukların çok fazla okuldan uzak kalmamalarını da göz önünde bulundurarak onları okula gitmeleri konusunda zorlamamalıdır. Ebeveynler bu tür bir durumla karşılaştıklarında çocuklarının uyum 
sürecini daha kolay atlatmasına yardımcı olabilmek için okula birlikte gitmeli, o dersteyken dışarıda beklemeli ve dersler bittiğinde birlikte eve dönerlerse çocuklar bu süreci daha kolay ve rahat bir şekilde atlatabilirler. Ancak bu durum sürekli olarak tekrarlanmamalıdır (Yurdakul, 2001).

İlgili literatür tarandığında okul öncesi eğitime başlangıç döneminde ebeveynlerin çocuklarının uyum sürecinde yaşadıkları problemlerin neler olduğunu anlatmaya çalışan çok az sayıda araştırma olduğu (Başaran, Gökmen ve Akdağ, 2014) belirlenmiştir. Ayrıca ebeveynlerin ve okul öncesi öğretmenlerinin bu süreçte nasıl bir tutum ve davranış içerisinde bulunması gerektiği konusuna ışık tutmak araştırmanın problem konusunu oluşturmaktadır. Konu alanıyla yapılan çalışmaların çoğunlukla akran ilişkileri, prososyal davranışlar ve mizaç özellikleri gibi çeşitli çalışmalardan oluştuğu belirlenmiştir (Yoleri, 2014).

\section{Araştırmanın Amacı}

$\mathrm{Bu}$ araştırmanın genel amacı, okul öncesi eğitimin başlangıcında yaşanılan uyum sürecine ilişkin ebeveynlerin görüşlerini belirlemektir. Bu genel amaca ulaşabilmek için ebeveynlerle yapılan görüşmelerde şu sorulara cevap aranmiştır.

- Çocuğunuz okul öncesi eğitime başladığında herhangi bir uyum sorunu yaşadınız mı? Eğer yaşadıysanız ne tür sorunlarla karşılaştınız açıklar mısınız?

- Karşılaştığınız sorunları gidermede ne tür yol ve yöntemler izlediğinizi anlatır mısınız?

- Bu süreçte kendinizde ve çocuğunuzda nasıl tutum ve davranış değişiklikleri gözlemlediğinizi açılar mısınız?

- Karşılaştığınız bu soruları gidermede öğretmeninizin, okul rehberlik servisinin ve okul idaresinin size herhangi bir katkısı oldu mu? Anlatır misiniz?

- Okul öncesi eğitime başlayacak ailelere bu konuyla ilgili neler tavsiye edersiniz?

- Konuya eklemek istediğiniz daha farklı görüşleriniz varsa lütfen belirtiniz? 


\section{Önem}

$\mathrm{Bu}$ araştırmadan elde edilen verilerden yola çıkarak daha önce bu konu alanıyla ilgili yapılan araştırma sonuçlarının karşılaştırılarak değerlendirilmesine olanak sağlayacaktır. Ayrıca konu ile ilgili literatüre bakıldığında okul öncesi eğitim sürecinin başlangıcında ebeveynlerin çocuklarının okula uyum sürecinde yaşadıkları sorunları inceleyen çalışmaların sınırlı sayıda olduğu görülmektedir. Okul öncesi eğitimin giderek önem kazandığı günümüz dünyasında bu eğitim kurumlarına çocuklarını ilk defa gönderen ebeveynlerin bu süreçte yaşadıkları durumları belirlemenin ve bunlara yönelik çözüm önerileri geliştirmenin alana katkı sağlayacağı düşünülmektedir. Bu kapsamda bu araştırmadan elde edilen veriler, çocuğu okul öncesi eğitim kurumlarına yeni başlayacak ailelere, öğretmenlere ve konuyla ilgili eğitim paydaşlarına rehberlik edeceği düşüncesiyle önemli görülmektedir.

\section{Yöntem}

$\mathrm{Bu}$ araştırmada nitel araştırma desenlerinden durum çalışması yöntemi kullanılmıştır. Durum çalışmalarının en önemli özelliği bir yâda birden fazla durumun bir arada ve derinlemesine araştırılmasına olanak sağlamasıdır (Yıldırım ve Şimşek, 2011).

\section{Çalışma Grubu}

Bu araştırmada amaçlı örnekleme yöntemlerinden ölçüt örnekleme yöntemi kullanılmıştır. Bu örneklemin seçilmesindeki temel neden önceden belirlenmiş bir dizi ölçütü karşılayan bütün durumların çalışılmasıdır. Burada anlatılmak istenen araştırma sürecinde kullanılacak olan ölçüt veya ölçütlerin araştırmacılar tarafından önceden hazırlanabilir veya oluşturulabilir olmasıdır (Yıldırım ve Şimşek, 2011). Araştırmanın çalışma grubunu 2018/2019 eğitim öğretim yılında Erzurum il merkezine bağlı toplam üç merkez ilçede, çocukları okul öncesi eğitim kurumlarına ilk defa başlayan ve devam eden 36-48 aylık yaş aralığına sahip çocukların ebeveynleri arasından gönüllü olarak çalışmaya destek vermek isteyenlerden oluştu- 
rulmuştur. Bu ebeveynlerin on sekiz tanesinin çocukları Erzurum ili Yakutiye merkez ilçesine bağlı okul öncesi eğitim kurumlarına, 14 tanesi Palandöken merkez ilçesinde bulunan okul öncesi eğitim kurumlarına ve geriye kalan sekiz tanesi de; Aziziye merkez ilçesinde bulunan okul öncesi eğitim kurumlarına devam etmektedir. Araştırmanın örneklemi otuz üç bayan ve yedi erkek olmak üzere toplam kırk ebeveyn oluşturmaktadır.

\section{Veri Toplama Aracı}

Araştırmanın veri toplama sürecinde araştırmacı tarafından geliştirilen yarı yapılandırılmış görüşme formu kullanılmıştır. Görüşme formunda yer alan sorular hazırlanırken ilgili literatür taraması yapılarak görüşme soruları hazırlanmıştır. Hazırlanan görüşme sorularının anlaşılırlığı ve araştırmanın amacına uygunluğu açısından okul öncesi eğitimi alanında uzman olan birisi Doç. Dr. iki tanesi Dr. Öğrt. Üyesi unvanına sahip; üç akademisyen ile iki tane okul öncesi öğretmeninin konuyla ilgili görüşleri alınmıştır. Uzman görüşleri alındıktan sonra çocuğunu okul öncesi eğitim kurumlarına gönderen altı ebeveyn ile yapılan ön uygulama çalışması sonucunda görüşme formunda yer alan sorular tekrar düzenlenmiş, eksik görülen sorular gözden geçirilmiş, yapılan düzeltmeler sonucunda görüşme formuna son şekli verilmiştir.

\section{Verilerin Toplanması ve Analizi}

Araştırma verileri Erzurum ili merkez ilçelerinde ebeveynlere uygulanan yarı yapılandırılmış görüşme formları kullanılarak elde edilmiştir. Araştırmacı çalışma grubuna giren ebeveynlerin çocuklarının devam ettiği okullara giderek uygun olan ebeveynlerle yüz yüze görüşerek, yüz yüze görüşme fırsatı bulamadığı ebeveynlerle telefon aracılığıyla görüşerek uygulamaya başlamadan önce görüşmenin içeriği, önemi ve amacı hakkında aileleri bilgilendirmiştir. Katılımcılar araştırmaya tamamen gönüllülük esasıyla katılmış ve her biriyle yaklaşık olarak 10 dakikalık bireysel görüşmeler gerçekleştirilmiştir. Araştırmadan elde edilen verilerin çözümlenmesinde içerik analizi ve betimsel analiz yaklaşımı birlikte kullanılmıştır. İçerik analizinde yapılan işlem, birbirine benzeyen verileri belirli kavram- 
lar ve temalar çerçevesinde bir araya getirmek ve bunları okuyucunun anlayabileceği bir biçimde düzenleyerek yorumlamaktır (Yıldırım ve Şimşek, 2011). Analiz sonuçları frekans ile ifade edilmiştir. Aynı süreç uygulama öğretmenine yönelik olarak hazırlanan görüşme formuyla tekrarlanmıştır. Ayrıca araştırmaya katılan öğrencilerin ve uygulama öğretmeninin konuyla ilgili görüşlerini daha net bir şekilde ortaya çıkarmak için doğrudan alıntılara da yer verilerek betimsel analiz tekniği de kullanılmıştır. Betimsel analiz; araştırmacılar için çalışmak istedikleri farklı olaylar ve olgular hakkında özet bilgi elde edebilmeleri için sıklıkla başvurulan bir yöntemdir (Büyüköztürk, Çakmak, Akgün, Karadeniz ve Demirel, 2008). Punch (2005) betimsel analiz kavramini; olguların nasıl başladığını ve devam ettiğini ya da bir durumun, kişinin ya da olayın neye benzediğinin resmini çizmek ve karmaşık şeyleri daha kavranabilir kılmak olarak tanımlamıştır. Her bir görüşün hangi sıklıkta tekrarlandığı belirlenerek elde edilen veriler sayısallaştırılmıştır. Verilerin bu şekilde sayısallaştırılarak çalışmanın geçerliliğini ve güvenilirliğini arttırılmaya çalışılmıştır.

\section{Bulgular}

Bu bölümde ebeveyn görüşme formundan elde edilen veriler tablolar haline getirilmiştir. Araştırmanın bulguları her bir görüşme sorusu altında altı başlık halinde toplanarak analiz edilmiştir. Bu başlıklar sırasıyla ebeveynlerin; çocukları okul öncesi eğitim kurumlarına ilk başladıklarında uyum sorunu yaşayıp yaşamadıkları; bu süreçte çocuklarında ne tür davranışlar gözlemledikleri, bu süreci geçirirken ne tür yöntemler izledikleri, bu süreçte kendilerinde gözlemledikleri davranış ve düşünce değişikliklerinin neler olduğu, yine bu dönemde öğretmeninizin, okul rehberlik servisinin ve okul yönetiminin konuyla ilgili tutumlarının neler olduğu, konuyla ilgili tavsiyeleri ve konuya eklemek istediğiniz görüşler başlığı altında açıklanmıştır. 


\section{Ebeveynlerin okula uyum sürecinde çocuklarında gözlemledikleri dav- ranışlara ilişkin görüşleri}

Ebeveynlerin bu süreçte çocuklarında ne tür davranışlar gözlemlediklerine ilişkin görüşleri Tablo 1'de verilmiştir.

Tablo1. Ebeveynlerin bu süreçte çocuklarında ne tür davranışlar gözlemlediklerine ilişkin görüşleri

\begin{tabular}{lll}
\hline Tema & Kodlar & Görüş sayısı \\
\hline Uyum sorunu yaşadı & & 30 \\
& Ayrilık kaygısı & 20 \\
& Okula gitmek istememe & 11 \\
& Korku & 8 \\
& Çekingenlik & 5 \\
& Kiskançlık & 4 \\
& Hırçınlık & 4 \\
& Paylaşmak istememe & 3 \\
& Sürekli ağlama & 2 \\
\hline Uyum sorunu yaşamadı & & 10 \\
& Anne babanın çalışıyor olması & 7 \\
& Çocuğumun öz güveni yüksek & 5 \\
& Sosyal ilişkileri güçlü & 4 \\
& Çocuğumu okulla ilgili bilgilendirdim & 4 \\
\hline
\end{tabular}

Tablo 1 incelendiğinde, ebeveynlerin okula uyum sürecinde sorun yaşayıp yaşamadıkları ve bu süreçte çocuklarında ne tür davranışlar gözlemlediklerine ilişkin olarak okula uyum sürecinde sorun yaşayan ebeveynlerin en çok yineledikleri görüşlerinin; ayrılık kaygısı (f:20), okula gitmek istememe (f:11), korku (f:8) ve çekingenlik (f:5) olduğu görülmektedir. E5. kodlu ebeveyn ayrılık kaygısı kodlu cevabını “ Evden, aileden ve bağlı olduğu yakın çevreden ilk defa ayrıldığı için bir ayrılık korkusu yaşadık" . E11. kodlu ebeveyn okula gitmek istememe kodlu cevabını “ K1zım 46 aylıkken kreşe başladı. Tabi ki ilk evden ayrıldığında çeşitli sorunlar yaşadık. Okul onun için değişik ve farklı bir ortamdı ve kimseyi tanımıyordu. O güne kadar anne ve anneanne de durmaya alışıktı. Uzun bir süre okula gitmek istemedi, alıştıkça, başardıkça, sevdikçe ve bir şeyler öğrenmeye başladıkça okula gitmeye başladı" E37. kodlu ebeveyn korku kodlu cevabını "Çocuğum kalabalık ve gürültülü ortamda korktuğu için okula gitmek istemedi. Bizlerden ilk defa ayrıldığı için çekingenlik ve 
korku yaşadı" E.18. kodlu ebeveyn çekingenlik kodlu cevabını " Okulda yapılan etkinliklere belli bir süre katılmadı. Yeni bir ortama girdiği için alışana kadar çekindi."

Tablo 1 incelenmeye devam edildiğinde, okula uyum sürecinde sorun yaşamayan ebeveynlerin bu süreçte çocuklarında gözlemledikleri davranışlara ilişkin en çok yineledikleri görüşlerinin; anne babanın çalışıyor olması (f:7), çocuğun öz güveninin yüksek olması (f:5), sosyal ilişkilerinin güçlü olması (f:4) ve çocuğumu okulla ilgili bilgilendirmiş olmam şeklinde olduğu görülmektedir. E.7. kodlu ebeveyn anne babanın çalışıyor olması kodlu cevabını "Anne ve baba olarak çalıştığımız için erken dönemde çocuğumuzu kreşe göndermiştik. Belki bu yüzden bilemiyorum ama biz bu dönemi çok kolay geçirdik" E.14. kodlu ebeveyn çocuğun öz güveninin yüksek olması kodlu cevabını “Oğlum son derece sosyal ve özgüveni fazla olan bir çocuktu. Onun bu özellikleri bize bu süreçte çok faydalı oldu. Bu dönem bizim için rahat geçti diyebilirim." E.28. kodlu ebeveyn çocuğumu okulla ilgili bilgilendirdim kodlu cevabını "Okula başlamadan önce çocuğuma okul kavramını nasıl anlatabileceğim konusunda küçük çaplı bir araştırma yapmıştım. Yaptığım bu araştırmadan öğrendiklerimi kızıma onun anlayabileceği şekilde anlatmaya çalıştım. Sanırım başarılı oldum çünkü okula ilk başladığımızda orası ona çokta yabancı bir yermiş gibi gelmedi." şeklinde ifade ettikleri belirlenmiştir.

\section{Ebeveynlerin bu süreci geçirirken ne tür yöntemler izlediklerine ilişkin görüşleri}

Ebeveynlerin bu süreci geçirirken ne tür yöntemler izlediklerine ilişkin görüşleri Tablo 2' de verilmiştir.

Tablo 2 incelendiğinde, ebeveynlerin bu süreci geçirirken ne tür yöntemler izlediklerine ilişkin olarak en çok yineledikleri görüşlerinin; öğretmenleriyle yakın iletişim (f:28), okulda onunla birlikte kalma (f:23), çocuğu sık sık ziyaret (f:15), korkusu hakkında konuşma(f:13) ve okulda ilgi çekici etkinliklerin yapılması (f:13) olduğu görülmektedir. E.40. kodlu ebeveyn öğretmeniyle yakın iletişim kodlu cevabını “Öğretmeniyle bu dönemde sürekli irtibat halindeydim. Ne yapmam ve nasıl davranmam gerektiği konusunda sürekli görüş alışverişinde bulunduk" E.25. kodlu ebeveyn okulda onunla birlikte kalma kodlu cevabını "İlk günlerde okulda beni görebileceği 
bir yerde bekledim. Daha sonra gün gün ona daha uzak bir yerlerden gözlemledim Bu böylece yaklaşık iki hafta gibi sürdü. Bu sürenin sonunda artık bize ihtiyact kalmadr." E.10. kodlu ebeveyn çocuğu sık sık ziyaret kodlu cevabını "Bu dönemde her boş olduğum anda çocuğumu sık sık okulda ziyaret ettim."

Tablo 2. Ebeveynlerin bu süreci geçirirken ne tür yöntemler izlediklerine ilişkin görüşleri

\begin{tabular}{lll}
\hline Tema & Kodlar & Görüş sayısı \\
\hline Ne tür yöntemler iz- & Öğretmenle yakın iletişim & 28 \\
ledikleri & Okulda onunla birlikte kalma & 23 \\
& Çocuğu sık sık ziyaret & 15 \\
& Korkusu hakkında konuşma & 13 \\
& Okulda ilgi çekici etkinliklerin yapılması & 13 \\
& Okul dışında ona daha fazla zaman ayırma & 12 \\
& Güven sağlama çalışmaları & 10 \\
& Kararlı bir tutum sergileme & 8 \\
& Okulun güzelliklerini anlatma & 8 \\
\hline
\end{tabular}

E.34. kodlu ebeveyn korkusu hakkında konuşma kodlu cevabını "Okul ortamı hakkında onunla sürekli konuştum. Arkadaşlarımın ve öğretmenin onu çok sevdiğini onunla oynamak istediklerini söyledim" E.9. kodlu ebeveyn okulda ilgi çekici etkinliklerin yapılması kodlu cevabını "Okulun ilk açıldı̆̆ı hafta öğretmenimiz çocukların ilgisini çekecek çok güzel etkinlikler yaptı. Palyaço gösterileri, resim çalışmaları, çeşitli oyunlar biz bu anlamda çok şanslıydık" şeklinde ifade etmişlerdir.

\section{Ebeveynlerin kendilerinde gözlemledikleri davranış ve düşünce deği- şikliklerinin neler olduğuna ilişkin görüşleri}

Ebeveynlerin bu süreçte kendilerinde gözlemledikleri davranış ve düşünce değişikliklerinin neler olduğuna ilişkin görüşleri Tablo 3'de verilmiştir.

Tablo 3 incelendiğinde, ebeveynlerin kendilerinde gözlemledikleri davranış ve düşünce değişikliklerinin neler olduğuna ilişkin olarak en çok yineledikleri görüşlerinin; kendilerini sorgulama (f:22), gerginlik (f:13), daha sakin davranma( f:10), alışamama(f:8) olduğu görülmektedir. E.36. kodlu ebeveyn kendini sorgulama kodlu cevabını "Okulun ilk haftasinda acaba bu sene onu okula göndermesem mi diye çok düşündüm. Yıpratıcıydı." 
E.39. kodlu ebeveyn gerginlik kodlu cevabını "Bu dönemde o okuldayken ben sürekli gergin ve mutsuzdum. Acaba ağhlyor mu, yemeğini yedi mi, arkadaşlarryla uyumu nasıl gibisinden bir soru soru kafa mı kurcalıyordu."

Tablo 3. Kendilerinde gözlemledikleri davranış ve düşünce değişikliklerinin neler olduğuna ilişkin görüşleri

\begin{tabular}{lll}
\hline Tema & Kodlar & Görüş sayısı \\
\hline Davranış ve düşünceler & Kendini sorgulama & 22 \\
& Gerginlik & 13 \\
& Daha sakin davranma & 10 \\
& Alışamama & 8 \\
& Özerkliğe ilk adım & 5 \\
& Kararlılık & 3 \\
\hline
\end{tabular}

E.8. kodlu ebeveyn daha sakin davranma cevabını " Bu dönemde çocuğuma karşı her zamankinden daha sakin ve daha anlayışlıydım. O benim rahat tavırlarımı görünce kendisi de her geçen gün daha rahat davranıyordu." E.15. kodlu ebeveyn alışamama ve özerkliğe ilk adım kodlu cevabını "Okulun açıldığı ilk haftadan itibaren o her geçen gün okula daha çok alıştı; sosyalleşti ve dil gelişimi fark edilir şekilde arttı. Ama ben halen onun okula gittiğine alışamadım. Sanırım onun artık toplumun bir bireyi olduğunu kabullenmem gerekecek". E.6. kodlu ebeveyn kararlılık kodlu cevabını "Bu dönemi eşim ve ben kararlı ve sabırl bir şekilde götürdük." şeklinde ifade etmişlerdir.

Ebeveynlerin bu süreçte öğretmenlerinin, okul rehberlik servisinin, okul yönetiminin konuyla ilgili tutum ve davranışlarının neler olduğuna ilişkin görüşleri

Ebeveynlerin bu süreçte öğretmenlerinin, okul rehberlik servisinin ve okul yönetiminin konuyla ilgili tutum ve davranışlarının neler olduğuna ilişkin görüşleri Tablo 4'de verilmiştir.

Tablo 4 incelendiğinde, ebeveynlerin bu süreçte öğretmenlerinin, konuyla ilgili tutum ve davranışlarının neler olduğuna ilişkin olarak en çok yineledikleri görüş̧lerinin; katkısı çok oldu (f:32), sürekli kolaylaştırıcıydı (f:30), sabırla davrandılar (f: 25) ve katkısı olmadı (f:6) şeklinde ifade etmişlerdir. Ebeveynlerin bu süreçte okul rehberlik servisinin konuyla ilgili 
tutum ve davranışlarının neler olduğuna ilişkin olarak en çok yineledikleri görüşlerinin; katkılarının olmadığı (f:24) ve hiç ihtiyaç duymadıklarını (f:10) belirtmişlerdir. Ayrıca ebeveynlerin bu süreçte okul idaresinin, konuyla ilgili tutum ve davranışlarının neler olduğuna ilişkin olarak en çok yineledikleri görüşlerinin katkılarının çok olduğu(f:21), katkıları olmadı(f:11) ve hiç ihtiyaç duymadım (f:4) şeklinde ifade etmişlerdir.

Tablo 4. Ebeveynlerin bu süreçte öğretmenlerinin, okul rehberlik servisinin ve okul yönetiminin konuyla ilgili tutum ve davranışlarının neler olduğuna ilişkin görüşleri

\begin{tabular}{lll}
\hline Tema & Kodlar & Görüşs sayısı \\
\hline Tutum ve davranışlar & Katkısı çok oldu & 32 \\
( Öğretmen) & Süreci kolaylaştırıcı & 30 \\
& Sabırlı & 25 \\
& Katkısı olmadı & 6 \\
\hline Okul rehberlik servisi & Katkıları olmadı & 24 \\
& Hiç ihtiyaç duymadım & 10 \\
\hline Okul idaresi & Katkıları çok oldu & 21 \\
& Katkıları olmadı & 11 \\
& Hiç ihtiyaç duymadım & 4 \\
\hline
\end{tabular}

E.3. kodlu ebeveyn öğretmenlerinin bu süreçte kendilerine çok katkısı olduğunu "Bu dönemde öğretmenimiz her zaman bizimle birlikteydi ve bize çok yardımo oldu" Okul rehberlik servisinin bu süreçte E.1 kodlu ebeveyn "Rehberlik servisi bu dönemde bize herhangi bir yardımda bulunmadı. Süreçle ilgili bizi herhangi bir şekilde bilgilendirmedi." Aynı süreçle ilgili olarak ebeveynler okul idaresinin E.22 kodlu ebeveyn "Okul yönetimi ne zaman gitsek konuyla ilgili bizi dinledi. Oldukça yapıcı ve samimi şekilde bize yardımo oldular." şeklinde görüş belirtmişlerdir.

\section{Ebeveynlerin konuyla ilgili tavsiyelerine ilişkin görüşleri}

Ebeveynlerin bu süreçte konuyla ilgili tavsiyelerine ilişkin görüşleri Tablo 5 'de verilmiştir.

Tablo 5 incelendiğinde, ebeveynlerin bu süreçte konuyla ilgili tavsiyelerinin neler olduğuna ilişkin olarak en çok yineledikleri görüşlerinin; kararlı ve sabırlı olma(f:25), birlikte hareket etme(f:14), iletişim dilini kullanma (f:12), ilgi çekici etkinlikler(f:8), araştırmacı ve bilinçli yaklaşım(f:8) ve gezi düzenleme (f:3) olduğu görülmektedir. 
Tablo 5. Ebeveynlerin bu süreçte konuyla ilgili tavsiyelerine ilişkin görüşleri

\begin{tabular}{lll}
\hline Tema & Kodlar & Görüşs sayısı \\
\hline Konuyla ilgili tavsiyeleri & Kararlı ve sabırlı olma & 25 \\
& Birlikte hareket etme & 14 \\
& İletişim dilini kullanmaları & 12 \\
& İlgi çekici etkinlikler & 8 \\
& Araştırmacı ve bilinçli yaklaşım & 8 \\
& Gezi düzenleme & 3 \\
\hline
\end{tabular}

E.33. kodlu ebeveyn kararlı ve sabırlı olma kodlu cevabinı "Sorunlarm bazen üzerine gitmeden zamana bırakmalarm tavsiye ederim. Bazen zaman, kararlılık ve sabır her şeye ilaç ve bazı şeyleri bir anda çözmeye çalışırsan hiç ummadığın şeyler daha da büyüyebiliyor" E.6 kodlu ebeveyn birlikte hareket etme kodlu cevabını "Bence bu aşamada çocuğun öğretmeni, okul idaresi ve rehberlik servisiyle çok yakın diyalog halinde hareket etmekte fayda var. Böyle yaptığınızda bu dönem daha kolay aşılıyor" E.26 kodlu ebeveyn iletişim dilini kullanmaları kodlu cevabını" Çocuğunuzla bu süreçte onu rahatlatacak şekilde konuyla ilgili sürekli konuşun. Onun bu konuyla ilgili bir sıkıntısı varsa bunu görmezden gelmek yerine bunu nasıl çözebileceğinizi, nasıl aşabileceğinizi ona konuşarak anlatmaya çalışı" E.2.kodlu ebeveyn ilgi çekici etkinlikler kodlu cevabını "Okulun ilk haftasında çocuklar bu dönemi daha kolay atlatsin, okulu ve arkadaşların daha yakından tanısın, kaynaşsın ve sosyalleşsinler diye okul idaresi tarafindan bu dönem çocuklarına yönelik ilgi çekici etkinlikler ve geziler düzenlenebilir" E.18.kodlu ebeveyn araştırmacı ve bilinçli yaklaşım kodlu cevabını "Ben bu süreçte çocuğum okula başlamadan önce bu süreçte nasıl davranmam konusunda çeşitli araştırmalar yapmıştım. Bize bu dönemde çok faydası olmuştu. Herkesin konuyla ilgili kendilerini bilinçlendirecek araştırmalar yapmasin tavsiye ederim."

\section{Ebeveynlerin konuya eklemek istedikleri görüşleri}

Ebeveynlerin konuya eklemek istedikleri görüşleri Tablo 6' de verilmiştir.

Tablo 6 incelendiğinde, ebeveynlerin bu süreçte konuya eklemek istedikleri görüşlerinin neler olduğuna ilişkin olarak en çok yineledikleri görüşlerinin; zorunlu olması(f:7), tam gün eğitim (f:5), yaş grupları(f:5), yaygınlaştırılması(f:4), yardımcı çalışanların niteliği(f:4) ve okul forması(f:1) olduğu görülmektedir. E.4. kodlu ebeveyn zorunlu olması kodlu cevabını 
"Okul öncesi eğitim hakkına tüm çocuklar kavuşabilsin ve aileler çocuklarım göndersinler diye zorunlu olmalı" E. 16. kodlu ebeveyn tam gün eğitim kodlu cevabını "Anne ve baba olarak çalıştığımız için çocuğumuzu güvenerek emanet edeceğimiz okul öncesi eğitim kurumları bizim gibi çalışan anne ve babaları düşünerek tam gün eğitim veren kurumlar haline getirilmeli. En azından isteyen velilere yönelik tam gün eğitim veren okul öncesi eğitim kurumları olmalı."

Tablo 6. Ebeveynlerin konuyla eklemek istedikleri görüşleri

\begin{tabular}{lll}
\hline Tema & Kodlar & $\begin{array}{l}\text { Görüş̧ Sa- } \\
\text { yısı }\end{array}$ \\
\hline \multirow{2}{*}{ Eklemek istedikleri görüşleri } & Zorunlu olması & 7 \\
& Tam gün eğitim & 5 \\
& Yaş grupları & 5 \\
& Yaygınlaştırılması & 4 \\
& Yardımcı çalışanların niteliği & 4 \\
& Okul forması & 1 \\
\hline
\end{tabular}

E.8 kodlu ebeveyn yaş grupları kodlu cevabını "Çocuklar arasındaki yaş gruplarn gelişim özellikleri açısından aylara göre bile çok değişiyor. Bu yüzden okul öncesi eğitim kurumları yaş grupları birbirine yakın çocuklar için ayrı ayrı olmalı ve buna son derece dikkat etmelidir." E.31 kodlu ebeveyn yaygınlaşt1rılması kodlu cevabını "Okul öncesi eğitim kurumları her yerde her mahallede olmalı ve herkes rahatlıkla ulaşabilmeli" E.9. kodlu ebeveyn yardımcı çalışanların niteliği kodlu cevabını "Okul öncesi eğitim kurumlarında öğretmene yardımoı olmak için çalıştırılan kişiler için taşımaları gereken niteliklere ilişkin milli eğitim bakanlığınca belirlenmiş belli kriterler mutlaka olmalı. Bu kişiler bu kriterler doğrultusunda buralarda çalıştırılmalı." E.29 kodlu ebeveyn okul forması kodlu cevabını "Diğer okul kademelerinde olduğu gibi okul öncesi eğitim kurumlarında da okul formaları olmalı bence. Çocuklarımız böylece kendilerini daha özel hissedebilirler." şeklinde görüş belirtmişlerdir.

\section{Sonuç, Tartışma ve Öneriler}

Bu araştırmada okul öncesi eğitime başlangıçta yaşanılan uyum sürecine ilişkin ebeveynlerin görüşlerini belirlenmiştir. Okula uyum sürecinde sorun yaşayan ebeveynler çocuklarında en çok gözlemledikleri davranışın ayrılık kaygısı olduğunu ifade etmişlerdir. Yapılan araştırmalarda okula 
uyum sorunu yaşayan çocukların genellikle küçük yaş grubu çocuklar olduğunu belirlenmiştir (Bahçeli, 2018, Datar, 2006 ve Yoleri, 2014). Balkaya (1998) yaptığı çalışmasında koruyucu özellikleri fazla olan ailelerin çocuklarının, özelikle küçük yaş grubunda yer alan çocukların, kız kardeşi olmayan çocukların ve tek çocuklu olan ailelerin, okula başlamadan önce yalnızca kendileri tarafından bakılan ailelerin çocuklarının okula başlama sürecinde çocuklarının ayrılık kaygısı yaşadıklarını tespit etmiştir. Bu durum araştırmaya katılan ebeveynlerin çocuklarıyla kurdukları iletişimin dilinin aşırı koruyucu ve bağımlı davranışlarından kaynaklanıyor olabilir. Ayrıca bu araştırmada anne ve babası çalışan çocukların okula uyum sürecinde genellikle sorun yaşamadıkları tespit edilmiştir. Bloom and Feschbach (1980) yılında yaptıkları çalışmada çocuğuna yeterli sevgi ve saygı gösteren ve onlara karşı demokratik tutumla, davranış içerisinde olan ve yeri geldiğinde onları denetleyen ailelerin çocuklarının anaokullarına başlarken çoğunlukla uyum sorunu yaşamadıkları belirlemişlerdir.

Ebeveynlerin çocukları okula ilk başladığı dönemde ne tür yöntemler izlediklerine ilişkin olarak genellikle öğretmenle yakın iletişim halinde olduklarını ve okulda birlikte kaldıklarını ifade etmişlerdir. Kahraman

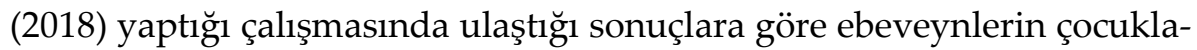
rını anne-baba olarak birlikte bıraktıklarını ve özellikle ilk hafta onları okulda beklediklerini ifade etmişlerdir. Aynı süreçle ilgili olarak annelerin bir bölümü çocuklarını ilk gün gözlemlediklerini belirtmişlerdir. Karaman, Şen, Alataş ve Tütüncü (2018) okula uyum sürecinde okul-aile iş birliği ve çocuğun ailesi ile kurduğu iletişimin niteliğinin çok önemli olduğu belirtmişlerdir. Kıldan (2012) yaptığı bir araştırmasında son dönemlerde ebeveynlerin eğitim ve öğretim sürecine katkılarının daha da arttı̆̆ını; ebeveynlerin öğretmenlerle iyi iletişim kurmalarının çocukların okula karşı olan tutumlarını olumlu yönde etkileyeceğini ifade etmiştir. Araştırmadan elde edilen bu sonuç ailelerin bu dönemde okulla işbirliğini arttırmasının önemini; bunu yaparken de sakin, sabırlı ve kararlı bir tutum içerisinde olmaları gerektiğini vurgulamaktadır.

Aynı süreçle ilgili olarak ebeveynlerin çocukları ilk kez okula başladıklarında kendilerinde gözlemledikleri davranış ve düşüncenin bu dönemde kendini sorguladıklarını ve gergin oldukları şeklinde ifade etmişlerdir. Soysal ve Bodur, (2004) çocuğun okula başladığı gün, aile bireyle- 
rinin rutin bir günmüş gibi davranmaları, çocuklarda korkuyu anımsatacak veya tetikleyecek davranışlardan kaçınmak gerektiğini ifade etmişlerdir. Zupancic and Kavcic (2011) yaptıkları araştırmasında; ebeveyn tutumlarının okula uyumu birçok değişkene göre çok daha fazla etkileyen bir değişken olduğu sonucuna ulaşmışlardır. Bu araştırmadan elde edilen sonuca göre ailelerinin çocuklarına karşı göstereceği tutum ve davranışların niteliği onların okula uyum sürecini arttırmakta veya azaltmakta önemli bir etken olabilir.

Araştırmadan elde edilen başka bir sonuca göre ebeveynlerin bu süreçte öğretmenlerinin, konuyla ilgili tutum ve davranışları olarak kendilerine çok katkıları olduğunu ve bu süreçte sürekli olarak kolaylaştırıcı bir rol üstlendiğini belirtmişlerdir. Aynı süreçle ilgili olarak ebeveynlerin çoğu okul rehberlik servisinin bu süreçte kendilerine katkısının olmadığını buna karşın okul idaresinin kendilerine katkı sunduklarını ifade etmişlerdir. Karaman, Şen, Alataş ve Tütüncü, B. (2018) okul öncesi dönemde okula uyum sürecine ilişkin öğretmen görüşlerini inceledikleri araştırmalarında bu süreçte özelikle okul yönetimine, öğretmenlere ve varsa okul rehberlik servisi öğretmenlerine önemli görevler düştüğü sonucuna ulaşmışlardır. Kıldan, (2012) yılında yaptığı araştırmasında, ebeveynlerin çocuklarında okul korkusunu yenmek için tercih ettikleri yöntemler olarak en sık olarak; çocuklarıyla konuştuklarını, öğretmeninden yardım aldıklarını, bir süre okulda beraber kaldıklarını, diğer velilere danışma ve profesyonel yardım alma şeklinde sıralamışlardır. Ebeveynlerin çocuklarının okula uyum sürecinde karşılaştıkları problemlerinin çözümü noktasında en çok destek aldıkları unsurlar arasında öğretmenlere yer verirken; aynı süreçle ilgili olarak ebeveynlerin profesyonel destek kavramina en az düzeyde yer vermesi okul rehberlik servislerinin bu konuda daha etkin olması gerektiğini ortaya çıkarmaktadır. Bu araştırma sonuçlarıyla adı geçen araştırmadan elde edilen sonuçların büyük ölçüde benzerlik gösterdiği belirlenmiştir.

Ebeveynlerin konuyla ilgili tavsiyelerinin en sik olarak diğer ebeveynlere kararlı ve sabırlı olmayı, aile bireyleri olarak birlikte hareket etmelerinin önemli olduğunu ifade etmişlerdir. Ebeveynlerin bu dönemde çocuklarına karşı gösterecekleri tutum ve davranışlarının niteliği ve yönü hiç şüphesiz ki ebeveynlerin eğitim seviyesiyle yakından ilgilidir. Yalçın 
(2016) okul öncesi dönem çocuklarının okula uyum süreci ile ebeveynlerinin çocuk yetiştirme tutumları arasındaki ilişki ve Karasan (2015) yaptıkları araştırmalarında; ebeveynlerin eğitim seviyesi düştükçe koruyucu ve otoriter tutum ve davranışlarında artış olduğunu; ebeveynlerin eğitim düzeyi yükseldikçe aşırı koruyucu tutumlarının azaldığını ve demokratik tutumların arttığını belirlenmiştir.

Ebeveynlerin okul öncesi eğitimin zorunlu olmasını, çalışan anne babalar için devlet okullarında eskiden olduğu gibi tam gün eğitim yapılmasını, çocukların yaş gruplarına göre (36-48 ay- $49-60$ ay ve 60 ve üstü aylar ) ayrılarak bu doğrultuda eğitim almalarını, okul öncesi eğitim kurumlarının yaygınlaştırılarak her semt ve mahallede olmasını, bu okullarda yardımcı görevli olarak çalıştırılan kişilerin niteliklerinin bir ölçüte bağlanmasını ve çocuklara kendilerini daha özel hissettirebileceği düşüncesiyle diğer eğitim kademelerinde olduğu gibi okul forması uygulamasının getirilmesi gerektiğini ifade etmişlerdir. OECD'nin 2015 yılında yayınladığı verilere göre ülkemizde okul öncesi eğitim kurumlarında okullaşma oranı günden güne artsa da ne yazık ki henüz istenilen noktada değildir. Birçok OECD ülkesinde okul öncesi eğitimde okullaşma oranı neredeyse \%100 yaklaşırken ülkemizde bu oran 2017- 2018 eğitim öğretim yılında \%66.88 olmuştur. Mevcut durum bile bir an öce gerekli alt yapı hazırlıklarının tamamlanarak, okul öncesi eğitimin zorunlu olması gerekliliğini ortaya çıkarmaktadır. Ebeveynlerin belirttiği diğer hususlarda okul öncesi eğitimin zorunlu olmasıyla birlikte kendiliğinden çözülebilecek durumlar olarak kabul edilebilir.

Araştırma sonuçlarından yola çıkarak; ebeveynlerin okula uyum sürecinde yaşadıklarına ilişkin olarak çocuklarının ayrılık kaygısı içerisinde olduklarını ve okula gitmek istemediklerini tespit edilmiştir. Bu süreçte ailelere çocuğuna karşı nasıl davranması ve ne tür bir tutum içerisinde olması gerektiğiyle ilgili profesyonel destek verilebilir. Ebeveynler bu süreçte çocuklarının öğretmeniyle yakın iletişim içerisinde olduklarını, çocuk okula alışıncaya kadar okulda onunla birlikte kaldıklarını ve çocuklarını bu dönemde sık sık ziyaret ettiklerini belirtmişlerdir. Bu durum okul aile işbirliğinin önemini bir daha ortaya çıkarmaktadır. Bu nedenle okul yönetimleri tarafından eğitim sürecinin tüm aşamasında, okul aile işbirliğini geliştirecek ve destekleyecek her türlü etkinlik ve faaliyetlere yer ve- 
rilmesi yararlı olabilir. Ebeveynler kendilerinde bu süreçte gözlemledikleri davranış ve düşünceler olarak çocuğumu acaba okula erken mi gönderdim diye kendilerini sorguladıklarını ve süreç boyunca gergin olduklarını belirtmişlerdir. Bu durumu gidermek için okul rehberlik servisleri tarafından eğitim öğretim dönemi başlamadan önce ebeveynlerin konuyla ilgili bilgilendirilmesi yararlı olabilir. Ayrıca yine bu dönemde çocuğun öğretmeni, okul rehber öğretmeni ve okul idarecilerinin katılımıyla çocukta ve ailede güven duygusunu oluşturmak adına ev ziyaretleri yapılabilir. Ebeveynler bu süreçte çocuklarının öğretmeniyle ve okul yönetimleriyle iletişimlerini olumlu cümlelerle ifade ederken okul rehberlik servislerinden konuyla ilgili kendilerine yeterli desteğin verilmediğini belirtmişlerdir. Bu durumu gidermek için okul rehberlik servislerinin süreç boyunca konuyla ilgili daha aktif rol almaları sağlamak adına okul yönetimlerinin bu süreçte okul rehberlik servisinin yapacağ 1 iş ve işlemlerle ilgili bir planlama ve organizasyon haritası çıkarılabilir. Ebeveynler bu süreci yaşayacak olan diğer ailelere süreç boyunca sabırlı ve kararlı olmalarını, ailenin bütün üyelerinin bu süreçte birlikte hareket etmesinin gerekliliğini vurgulamışlardır. Ebeveynler olarak bilinçli anne ve baba olmak için yaşam boyu öğrenme kavramından hareketle kendimizi sürekli geliştirmemizin bu dönemde çocuğumuzun hayatına olumlu dokunuşu olacağ gibi olaylara ve olgulara farklı açılardan bakmamızı sağlayabilir. Öte yandan gerekli hazırlıkların bir an önce tamamlanarak okul öncesi eğitimin zorunlu hale getirilmesi, geleceğin mimarı çocuklar için en güzel yatırımlardan biri olabilir. 


\title{
EXTENDED ABSTRACT
}

\section{Parents' Opinions on the Adaptation Process at the Beginning of Preschool Education}

\author{
Ayhan Bulut \\ Bayburt University
}

From the birth of the child until the day of basic education, the education provided by the state or private institutions and educational institutions that prepare children for basic education in a qualified and planned way is called pre-school education (Şepitçi, 2018). In other words, by supporting the children's social, linguistic, cognitive, emotional and psychomotor development stages in a healthy manner, it is the first process of education to teach the cultural values of the society in which the child grows in accordance with their own development and has a very important role in shaping their personality and structure (Aslanargun ve Tapan 2012, Balaban, 2017). The process of pre-school education is the fastest period of a child's development and change. In this period, the child starts to create permanent behavioral changes according to the quality of education given to him (Şahin, 2000).

Pre-school education institutions have a very important role in shaping the child's life after the formal education. For the children, preschool education institutions reflect the existence of an environment in which they leave the family, begin to stand on their own feet, begin to take their responsibilities slowly and open the door to socialization. The nature of the school adaptation process depends on many factors such as the school readiness level, socio-economic status, family education status and demographic characteristics of the child's environment (Reynolds and Bezruczko, 1993).

The concept of adaptation to school refers to all of the behavioral and academic responses of the child to external stimuli from the social environment. The existence and content of the problems experienced in this process may adversely affect their adaptation to school (Gresham and Elliott, 1987, Seven, 2011). In the beginning of pre-primary education, the child may be confronted with a variety of problems, as he is heavily 
committed to his parents and leaves the family environment in which he feels safe. It is very important for the child to get used to the new process in the fastest and the most beautiful way (Kaya ve Akgün, 2016).

According to Aydoğmuş (2001) the child may not want to go to school at the beginning and school fear and anxiety may also develop in this period. The main reason for this fear is that the child will be separated from his mother. Durak (2011) stated that most of the children may have difficulties in adaptation, which may occur in various ways in the early days when they start school. A significant portion of these problems are solved in the first weeks of school. However, the individual differences of the students, the approaches and attitudes of the family to the subject may cause this process to prolong. Children feel safer when they see that their parents and teachers are in close contact with each other in this process (Carlisle. E., Stanley, L. and Kemple K.M 2005).

When the related literature was reviewed, it was determined that there were very few studies that attempted to explain the problems that parents experienced in the adaptation process of their children at the beginning of pre-school education (Başaran, Gökmen ve Akdağ, 2014). In addition, shedding light on how parents and preschool teachers should behave in this process is the subject of this research. The data obtained from this study is considered important in view of the fact that it will guide the families whose children will start the pre-school education institutions, teachers and the related education stakeholders.

\section{Objective}

The general purpose of this study is to determine the views of parents about the adaptation process experienced at the beginning of preschool education. In order to reach this general aim, the following questions were sought in the interviews with parents.

- Did your child experience any adaptation problems when he started preschool education? If so, can you explain what kind of problems did he face?

- Can you tell us what kind of ways and methods you have followed to solve your kid's problems? 
- In this process, can you explain the attitude and behavior changes you observed in yourself and your child?

- Has the teacher, school guidance service and school administration made any contribution to solve these problems? Can you tell us?

- What would you recommend to families whose children will start preschool education on this issue?

- Please specify if you have different opinions you would like to add to the topic?

\section{Method}

In this study, case study method, which is one of the qualitative research designs, was used. The most important feature of the case studies is that it enables the investigation of one or more situations together and in depth (Yıldırım \& Şimşek, 2011).

\section{Findings}

Parents who experienced problems in their children's school adaptation stated that they observed behaviors such as separation anxiety, unwillingness to go to school, fear and shyness in their children. Regarding the methods the parents applied in this process, they stated that they were in close contact with their child's teachers, preferred to stay with the child in the school, visited the child frequently, and talked to the child about his fear. In this process, the parents were asked about their own behavior and thought changes; they stated that they were questioning themselves, they were nervous, they behaved calmer, they could not get used to this situation. Parents stated that the opinions of the teachers about their attitudes and behaviors in the process were very high and they had a continuous facilitating role, they were patient and they had no contribution in this process. Parents, in relation to the same process, stated that the school guidance service had no contribution to them and that they did not need any help at all. Parents, however, stated that the school administration had a lot of contribution or no contribution to this issue, or they had no need for such assistance. Parents are advising families who will send their children to preschool education institutions 
for the first time; to be stable and patient, to act together with the family, to use language of communication well, to require interesting activities in the school, and to be in a questioning and conscious approach about how to behave in this process. Parents also add these opinions on the subject; that preschool education should be compulsory and full-time education should be provided in public schools, children should be educated according to age groups and pre-school education should be widespread for all, new criteria should be introduced for the quality of employees in the school, the school uniform should be used in pre-school education institutions as it will make the children feel more special and will give them a sense of belonging.

\section{Conclusion and Recommendations}

Based on the results of the research; it was determined that the children were in a concern of separation and unwilling to go to school in the school adaptation process. In this process, families can be given professional support on how they should treat their child and what kind of harmony they should have with their child. Parents stated that their children were in close contact with their children's teacher and that they stayed with the children at school until they got used to school and they visited their children frequently during this period. This situation raises the importance of school-family cooperation. For this reason, it can be useful to include all kinds of activities in the whole phase of the education process by the school authorities to develop and support school-family cooperation. Parents stated that they observed their own behavior and thoughts in this process and stated that they asked themselves "Did I send my child to school at an early age?" and admitted that they were nervous throughout the process. In order to remedy this situation, it may be useful to inform parents about the subject before the beginning of the education period by the school guidance services. In this period, children and their parents can be visited in their homes in order to create a sense of trust in the child and family with the participation of the teachers, school guidance teacher and school administrators. While parents were satisfied with their communication with the school teachers and school administrators, they stated that the school guidance services did not give them enough support. In order 
to solve this problem, school administrations may prepare a planning and organization directive related to the work and operations of the school guidance service in order to ensure that school guidance services take a more active role throughout the process. Parents advised other families who will experience this process to be resolute and patient and expressed the need for all members of the family to act together throughout the process. In order to be a conscious mother or father, the concept of lifelong learning can help us to look at events and situations from different perspectives, as our continuous improvement of ourselves will have a positive impact on our child's life. On the other hand, after making the necessary preparations more quickly, then pre-school education must be compulsory in our country, which may be one of the best contributions to the future of our children.

\section{Kaynakça / References}

Aslanargun, E. ve Tapan, F. (2012). Okul öncesi eğitim ve çocuklar üzerindeki etkisi. Abant İzzet Baysal Üniversitesi Dergisi, 11(2), 219-238.

Aydoğmuş K, Baltaş A; Batlaş, Z (2001). Ana-baba okulu. İstanbul: Remzi Kitabevi,.

Bağçeli Karaman, P., Şen, T., Alataş, S. ve Tütüncü, B. (2018). Okul öncesi dönemde okula uyum sürecine ilişkin öğretmen görüşleri. Abant İzzet Baysal Üniversitesi Eğitim Fakültesi Dergisi, 18(2), 681-701.

Bahçeli, K. P. (2018). Okul öncesi dönem çocuklarının okula uyum sürecine ilişkin anaokulu öğretmenlerinin ve annelerinin görüşleri. Erken Çocukluk Çalışmaları Dergisi, 2, 3-20.

Balaban, E. (2017). Türkiye'de okul öncesi eğitim ve okul öncesi öğretmenlerinin yönetim sürecinde karşılaştıkları sorunlar. Tezsiz yüksek lisans projesi. Trakya Üniversitesi Sosyal Bilimler Enstitüsü, Edirne.

Balkaya, İ. (1998). Anaokuluna yeni başlayan çocukların okula uyum süreçlerini etkileyen faktörlerin incelenmesi. Yayımlanmamış Yüksek Lisans Tezi. Hacettepe Üniversitesi. Sağlık Bilimleri Enstitüsü. Ankara.

Başaran, S; Gökmen, B ve Akdağ, B.(2014). Okul öncesi öğrencilerinin okula uyum sürecinde öğretmenlerin karşılaştığı sorunlar ve çözüm önerileri. Uluslararası Türk Eğitim Bilimleri Dergisi, 2(2), 197-222. 
Bloom, F.,S. ve Gaunghran, J. (1980). The child's tie to both parents: separation pattern and nursery school adjustment. American Journal of Orto Psychiatry, 50(3), 505-552.

Büyük Öztürk, Ş., Kılıç Çakmak, E., Akgün, Ö.E., Karadeniz, Ş. ve Demirel, F. (2014). Bilimsel araştırma yöntemleri (17. Baskı). Ankara: Pegem Yayınları.

Carliste, E., Stanley, L. ve Kemple K.M. (2005). Opening doors: Understanding school and family involvement. Early Childhood Education Journal, 33(3), 155-165.

Datar, A. (2006). Does delaying kindergarten entrance give children a head start? Economics of Education Review, 25(1), 43-62.

Deretarla Gül, E.(2019). Okula başlama ve okula uyum süreci.(www.google akademik.com.( 07.04.2019).

Durak, T.( 2011). Okul Öncesi Çocuk ve... İçinde “Okul Öncesi Çocuk ve İlk Öğretmeni". Ankara: Nobel Yayınları.

Gresham, F. M. ve Elliott, S. N. (1987). The relationship between adaptive behaviour and social skills: Issues in definition and assessment. Journal of Special Education, 21(9), 167-181.

Kahraman, B. P.(2018). Okul öncesi dönem çocuklarının okula uyum sürecine ilişkin anaokulu öğretmenlerinin ve annelerinin görüşleri. Erken Çocukluk Çalışmaları Dergisi, 2(1), 3-20

Karasan, S. (2015). Bireylerin ebeveynlerinin göstermiş oldukları ebeveyn tutumlar ile sahip oldukları düşünme stilleri arasındaki ilişki. Yayımlanmamış Yüksek Lisans Tezi, Haliç Üniversitesi, sosyal Bilimler Enstitüsü, İstanbul.

Kaya, Ö.S ve Akgün, E. (2016). Okul öncesi dönemdeki çocukların okula uyum düzeylerinin çeşitli değişkenler açısından incelenmesi. İlköğretim Online, 15(4), 1311-1324.

Kıldan, O. A. (2012). Okul öncesi öğretmenlerinin ve ebeveynlerin okul öncesi dönemdeki çocukların okul korkularına ilişkin görüşleri. Türk Eğitim Bilimleri Dergisi, 10(1), 49-73.

Ladd, G. W ve Price, J. M. (1987). Predicting children's social and school adjustment following. Developmental Psychology, 58(5), 1168-1189.

MEB(2015). UNICEF okula uyum programı eğitici eğitim kitabı. s.12-31.Ankara: MEB.

Punch, K.F. (2005). Sosyal araştırmalara giriş. Çev. D. Bayrak, H.B. Arslan, ve Z. Akyüz. Ankara: Siyasal Kitabevi. 
Reynolds, A.J and Bezruczko, N.(1993). School adjustment of children at risk through fourth grade. Merrill Palmer Quarterly, 16,117-132.

Seven, S.( 2011). Okula uyum öğretmen değerlendirmesi ölçeğinin geliştirilmesi. Türk Eğitim Bilimleri Dergisi, 9(1), 29-42.

Soysal, Ş., Bodur, Ş. (2004). Bir büyüme masalı: Okul korkusu. Sürekli Tıp Ĕğitim Dergisi, 13(6), 234-236.

Şahin, F. (2000). Okul öncesinde fen bilgisi öğretimi ve aktivite örnekleri. İstanbul: Ya-Pa.

Şepitçi, M. (2018). Okul öncesi eğitim kurumlarına devam eden 5-6 yaş çocuklarının öz düzenleme becerilerinin okul uyumu ile ilişkisinin incelenmesi. Yayımlanmamış Yüksek Lisans Tezi. İstanbul Arel Üniversitesi. Sosyal Bilimler Enstitüsü. İstanbul.

Yalçın, V.(2016). Okul öncesi dönem çocuklarının okula uyum süreci ile ebeveynlerinin çocuk yetiştirme tutumları arasındaki ilişki. Anadolu Üniversitesi, Eğitim Bilimleri Enstitüsü. Yayımlanmamış Yüksek Lisans Tezi. Eskişehir.

Yeşilyaprak, B.(1989). Anne baba tutumlarının kişilik gelişimi üzerindeki etkisine ilişkin bir araştırma. Yapa 6. Okul Öncesi Ĕ̆itimi Yaygınlaştırma Semineri, 11-13 Mayıs, İstanbul, s.10.

Yıldırım, A.ve Şimşek, H.(2011). Sosyal bilimlerde nitel araştırma yöntemleri. (Sekizinci Baskı). Ankara: Seçkin Yayıncılık.

Yoleri, S. (2014). The effects of age, gender, and temperament traits on school adjustment for preschool children. e-International Journal of Educational Research, 5(2), 54-66.

Yoleri, S. ve Tanış, H.M. (2014).İlkokul birinci sınıf öğrencilerinin okula uyum düzeylerinin etkileyen değişkenlerin incelenmesi. Sosyal Bilimler Enstitüsü Dergisi, 4(2),130-141.

Yurdakul, S.(2001). Ana baba el kitabı. Adana: Nobel Kitabevi.

\section{Kaynakça Bilgisi / Citation Information}

Bulut, A. (2019). Okul öncesi eğitime başlangıçta yaşanılan uyum sürecine ilişkin ebeveynlerin görüşleri. OPUS-Uluslararası Toplum Araştırmalan Dergisi, 13(19), 656-681. DOI: 10.26466/opus.571801. 